J Arid Land (2013) 5(4): 531-541

doi: $10.1007 / \mathrm{s} 40333-013-0178-7$

jal.xjegi.com; www.springer.com/40333

\title{
Gas exchange of Populus euphratica leaves in a riparian zone
}

\author{
Dieter OVERDIECK ${ }^{1 *}$, Daniel $\mathrm{ZICHE}^{2}$, RuiDe $\mathrm{YU}^{3}$ \\ ${ }^{1}$ Institute of Ecology/Ecology of Woody Plants, TU-Berlin, D-14195 Berlin, Germany; \\ ${ }^{2}$ von Thuenen-Institut, Institute of Forest Ecology and Forest Inventory, D-16225 Eberswalde, Germany; \\ ${ }^{3}$ Xinjiang Institute of Ecology and Geography, Chinese Academy of Sciences, Urumqi 830011, China
}

\begin{abstract}
Riparian vegetation belts in arid regions of Central Asia are endangered to lose their ecosystem services due to intensified land use. For the development of sustained land use, management knowledge of plant performance in relation to resource supply is needed. We estimated productivity related functional traits at the edges of the habitat of Populus euphratica Oliv. Specific leaf area (SLA) and carbon/nitrogen (C/N) ratio of $P$. euphratica leaves growing near a former river bank and close to moving sand dunes in the Ebinur Lake National Nature Reserve in Xinjiang, Northwest China (near Kazakhstan) were determined and daily courses of $\mathrm{CO}_{2}$ net assimilation $\left(P_{\mathrm{N}}\right)$, transpiration $(\mathrm{E})$, and stomatal conductance $\left(\mathrm{g}_{\mathrm{s}}\right)$ of two consecutive seasons were measured during July-August 2007 and June-July 2008. Groundwater level was high (1.5-2.5 m below ground) throughout the years and no flooding occurred at the two tree stands. SLA was slightly lower near the desert than at the former river bank and leaves contained less $\mathrm{N}$ in relation to $\mathrm{C}$. Highest $\mathrm{E}$ and $\mathrm{g}_{\mathrm{s}}$ of $P$. euphratica were reached in the morning before noon on both stands and a second low maximum occurred in the afternoon despite of the unchanged high levels of air to leaf water vapor pressure deficit (ALVPD). Decline of $g_{s}$ in $P$. euphratica was followed by decrease of $E$. Water use efficiency (WUE) of leaves near the desert were higher in the morning and the evening, in contrast to leaves from the former river bank that maintained an almost stable level throughout the day. High light compensation points and high light saturation levels of $P_{\mathrm{N}}$ indicated the characteristics of leaves well-adapted to intensive irradiation at both stands. In general, leaves of $P$. euphratica decreased their $\mathrm{g}_{\mathrm{s}}$ beyond $20 \mathrm{~Pa} / \mathrm{kPa}$ ALVPD in order to limit water losses. Decrease of $E$ did not occur in both stands until $40 \mathrm{~Pa} / \mathrm{kPa}$ ALVPD was reached. Full stomatal closure of $P$. euphratica was achieved at $60 \mathrm{~Pa} / \mathrm{kPa}$ ALVPD in both stands. E through the leaf surface amounted up to $30 \%$ of the highest $E$ rates, indicating dependence on water recharge from the ground despite of obviously closed stomata. A distinct leaf surface temperature $\left(T_{\text {leaf }}\right)$ threshold of around $30^{\circ} \mathrm{C}$ also existed before stomata started to close. Generally, the differences in gas exchange between both stands were small, which led to the conclusion that micro-climatic constraints to $\mathrm{E}$ and photosynthesis were not the major factors for declining tree density with increasing distance from the river.
\end{abstract}

Keywords: Populus euphratica; water vapor pressure deficit; transpiration; stomatal conductance; water use efficiency; leaf functional traits

Citation: Dieter OVERDIECK, Daniel ZICHE, RuiDe YU. 2013. Gas exchange of Populus euphratica leaves in a riparian zone. Journal of Arid Land, 5(4): 531-541. doi: 10.1007/s40333-013-0178-7

The phreatophyte Populus euphratica Oliv. (Tugai poplar, Euphrates poplar) is often the dominant tree species in the endangered river plain woodlands of arid and semi-arid regions from the Near East to Cen- tral Asia (Walter et al., 1983; Thomas et al., 2000) because of its tolerance to severe drought, high salinity and alkalinity of soils as long as its roots reach the capillary fringe of groundwater (Chen et al., 2006a).

*Corresponding author: Dieter OVERDIECK (E-mail: overdieck.d@mailbox.tu-berlin.de)

Received 2012-11-27; revised 2013-01-03; accepted 2013-02-05

(C) Xinjiang Institute of Ecology and Geography, Chinese Academy of Sciences, Science Press and Springer-Verlag Berlin Heidelberg 2013 
Therefore, in Central Asia this species has been found suitable in many cases to improve the ecological potential by reforestation of degraded landscapes (Lamers et al., 2006; Khamzina et al., 2008; Yu, 2008; Säumel et al., 2011). Especially, the extremely high salt tolerance of this poplar has been studied under various aspects (Fung et al., 1998; Chen et al., 2001, 2002; Arndt et al. 2004; Chang et al., 2006). Also in the Ebinur Lake National Nature Reserve in the northwest of Xinjiang, China, close to the border of Kazakhstan, it is the major tree species. Knowledge about the response of $P$. euphratica to resource supply is needed for the development of sustained land use management (Zhao et al., 2012). Therefore, we measured leaf properties and gas exchange as productivity related functional traits. We selected two stands of $P$. euphratica for our measurements in the Ebinur Lake National Nature Reserve at both edges of an environmental transect which was set from a former river bank to the sand dunes of the desert. As this area is situated in a deep basin surrounded by high mountain ridges, the groundwater level is, without abundant oscillations, comparatively stable and close to soil surface near approaching sand dunes as well as along former beds of small rivers with relatively dense vegetation belts ( $\mathrm{Yu}, 2008)$. Therefore, change of groundwater depths is not the ecological factor which dominates water uptake and water supply of the plants at our study site. Also, inundation water is not available in relevant amounts in early summer, like for instance in the Tarim River Basin (Thomas et al., 2006). It was also found that, generally, inundation by flooding and unsaturated soil moisture is much less relevant to growth than the access to groundwater for the vegetation type in which $P$. euphratica belongs to the dominant species (Bruelheide et al., 2010). But if there is a salt concentration by high evaporation in the upper soil, this can be reduced by fresh water inundation and thus salt stress can be mitigated. However, as abundant flooding is lacking at our study site, dilution of salt can be neglected, or even increased salinity can be expected in the long term. On the one hand, there is enough water for roots, but on the other hand, it can be expected that after sunrise air to leaf water vapor pressure deficit (ALVPD) will increase considerably and continuously, especially during summer and therefore, water flow through plants and water losses to the atmosphere can be extremely high (Gries et al., 2003). Vessels might become incapable to transport enough water in order to equalize water loss by transpiration (E) of leaves exposed to very dry air (Hukin et al., 2005). Former studies showed that ALVPD is the most appropriate variable (Aphalo and Jarvis, 1991) determining both $\mathrm{E}$ and stomatal conductance $\left(\mathrm{g}_{\mathrm{s}}\right)$. Most published measurements (Monteith, 1995) show that $g_{s}$ decreases linearly with increasing E. On the other hand, there seems also to be a 'regime' under which E remains constant or begins to decrease along with increasing ALVPD (Monteith, 1995). This response could be consistent with a certain sensing of the $E$ rate itself by leaves rather than a passive responding on the saturation deficit (Meinzer and Grantz, 1991; Mott and Parkhurst, 1991). It is not known to which type $P$. euphratica belongs and if this desert and semi-desert plant can reduce $\mathrm{E}$ and $\mathrm{g}_{\mathrm{s}}$ by optimizing water losses to avoid water stress in leaf tissues. A coupled $\mathrm{CO}_{2}$ and $\mathrm{H}_{2} \mathrm{O}$ gas exchange model at the leaf scale was recently developed, which is capable of predicting $\mathrm{CO}_{2}$ net assimilation $\left(P_{\mathrm{N}}\right)$ in response to many regulating environmental factors, but predictions of $g_{s}$ and E are 'less satisfactory' (Zhu et al., 2010). One reason for the lack of sufficiently reliable parametrization might be the lack of enough measurements with special focus on $\mathrm{E}$ and $\mathrm{g}_{\mathrm{s}}$ of $P$. euphratica leaves in addition to $P_{\mathrm{N}}$ measurements at constant water supply for roots. Our measurements were conducted to improve the understanding of stomatal aperture and gas exchange of this species under stress induced by climatic factors in the field (air temperature up to $42^{\circ} \mathrm{C}$ and ALVPD up to $80-90 \mathrm{~Pa} / \mathrm{kPa}$ ).

\section{Materials and methods}

\subsection{Study sites}

The measurements were accomplished in the Ebinur Lake National Nature Reserve located in the north-western part of the Junggar Basin, Xinjiang, China. Two of eight $100 \mathrm{~m} \times 100 \mathrm{~m}$ plots, on which tree stand characteristics were investigated by $\mathrm{Yu}$ (2008), were selected for $\mathrm{H}_{2} \mathrm{O}$ and $\mathrm{CO}_{2}$ gas exchange 
measurements on leaves of $P$. euphratica. One of the studied plots was close to the sand dunes of the spreading Gurbantunggut Desert and the other was $4 \mathrm{~km}$ apart near the river bank of the former river Aqikesu. The river Aqikesu has lost its over groundwater flow from the mountains as well as its connection to the Ebinur Lake caused by water withdrawal for cotton field irrigation. Corner point coordinates of the former river bank plot $(289 \mathrm{~m}$ asl) were

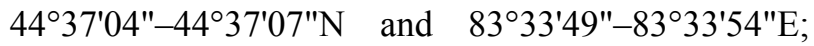
coordinates of the desert edge plot ( $288 \mathrm{~m}$ asl) were

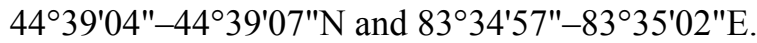

\subsection{Climate, soil and groundwater}

The region has an arid, continental climate with little precipitation and strong winds. Annual mean temperature was recorded to be $6.8^{\circ} \mathrm{C}$ and mean annual precipitation varies between 90.9 and $163.9 \mathrm{~mm}(n=40$ years). In January temperatures of $<-30^{\circ} \mathrm{C}$ are reached and in July regularly $40^{\circ} \mathrm{C}(\mathrm{Yu}, 2008)$.

Salinization of the sandy soils was strong on both plots and salt silt, salt crusts, and salty loose mineral material, not only of $\mathrm{NaCl}$ but also of great amounts of $\mathrm{Na}_{2} \mathrm{SO}_{4}$, were found on the surface and in the uppermost soil layer $(10 \mathrm{~cm})$. There, conductivity was $27.7 \mathrm{~ms} / \mathrm{cm}$ at the former river bank and $15.5 \mathrm{~ms} / \mathrm{cm}$ near the desert edge (saturated paste); $\mathrm{pH}$ in the upper soil layer $(10-60 \mathrm{~cm})$ was 8.9 near the former river bank and 8.6 at the edge of the sand desert $\left(\mathrm{CaCl}_{2}\right.$ extract). Every two weeks in the growing seasons during two years (2006 and 2007), the groundwater level was measured in wells close to both plots ( $\mathrm{Yu}, 2008)$. The lowest groundwater level was reached during July-August with $2.2 \mathrm{~m}$ below surface at the former river bank plot and with $2.4 \mathrm{~m}$ at the desert edge plot (Fig. 1).

\subsection{Trees}

$P$. euphratica is the dominant tree species growing spontaneously on both plots. On the former river bank plot 185 trees with crown coverage of $18 \%$ were counted, and on the plot near the sand dunes 33 individuals with crown coverage of $2.5 \%$ were counted. Despite the clear differences in crown coverage and stem density, height and stem diameter at breast

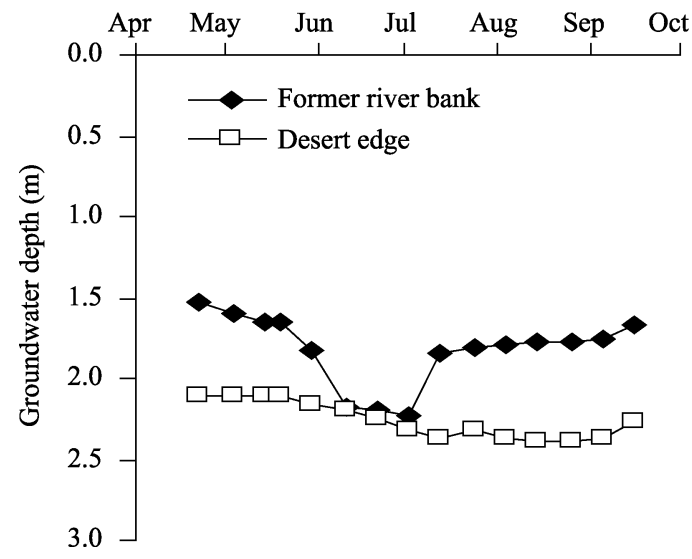

Fig. 1 Groundwater depth at two Populus euphratica stands in a riparian zone of northwestern China during April-October 2007. The data were cited from Yu (2008).

height were not statistically different between the two plots. Mean height was $5.0 \pm 3.2 \mathrm{~m}$ (median: $4.7 \mathrm{~m}$ ) near the former river bank and $3.7 \pm 1.5 \mathrm{~m}$ (median: 3.3 $\mathrm{m})$ near the edge of the desert. Mean of breast height amounted to $22.0 \pm 19.7 \mathrm{~cm}$ (median: $16.2 \mathrm{~cm}$ ) near the former river bank and $16.0 \pm 11.2 \mathrm{~cm}$ (median: $12.1 \mathrm{~cm}$ ) near the desert dunes ( $\mathrm{Yu}, 2008)$. Trees were 30-50 years old on both plots.

\subsection{Gas exchange and related parameters}

$\mathrm{H}_{2} \mathrm{O}$ and $\mathrm{CO}_{2}$ gas exchange were measured from dawn to dusk of 19 July-16 August 2007 by means of a WALZ portable photosynthesis system (HCM-1000, Germany) on randomly selected sun-exposed leaves of 10 different trees on both plots, avoiding any preference of either broad-ovate or lanceolate leaves (one leaf/day and one tree/day, one complete data set per minute). Thus, thirteen daily courses of gas exchange were obtained from leaves on the plot near the former river bank and nine daily courses of leaves were obtained from trees on the plot near the bare sand dunes. In 2008, from 28 June-9 July, these measurements were repeated for eleven days near the former river bank and once in the stand near the sand dunes (total number of daily courses: 34 ). Crowns were reached by placing the instrument on a scaffold.

After the measurements, leaves were cut, and their contours were directly copied on paper with a pencil and contours were cut out by scissors. Later on, the areas of the paper copies were measured in Berlin with the area meter LI-3000 (Li-cor, USA). Air dried 
leaves were also transported in paper bags to Berlin and dried at $85^{\circ} \mathrm{C}$ for 24 hours and their dry masses were weighed. In addition, 157 leaves from 10 trees on the plot near the former river bank and 91 leaves from 10 trees in the stand near the sand dunes were collected at random in 2008 and area and mass values were obtained as described above. Leaf collection was repeated in September 2010 (10 trees/plot and 20 leaves/tree). Gas exchange rates were expressed on unit leaf area and mass unit basis. Leaf area and dry mass (with petiole) were used for calculating specific leaf area (SLA). Dried leaves of the first year were pulverized and nitrogen $(\mathrm{N})$ and carbon $(\mathrm{C})$ contents were determined with the $\mathrm{C} / \mathrm{N}$-analyzer $\mathrm{CHN} 932$ (Leco-Instruments, Germany). Parallels of chemical analyses deviated by $3 \%$ from each other.

\subsection{Data analysis}

\subsubsection{Mean daily courses}

Means of $P_{\mathrm{N}}, \mathrm{E}, \mathrm{g}_{\mathrm{s}}$, and ALVPD were calculated from all original data of the first year within $10 \mathrm{~min}$. Wide data classes (SAS 9.2 program) were only for $P_{\mathrm{N}}$ and $\mathrm{E}$ at $\mathrm{g}_{\mathrm{s}}>1 \mathrm{mmol} \mathrm{H}_{2} \mathrm{O} /\left(\mathrm{m}^{2} \cdot \mathrm{s}\right)$. Results were then transferred to Excel graphs.

\subsubsection{Water use efficiency (WUE) courses}

Mean daily courses of the quotient $P_{\mathrm{N}} / \mathrm{E}\left(\mu \mathrm{mol} \mathrm{CO}_{2}\right.$ $/ \mathrm{mmol}_{2} \mathrm{O}$ ) were calculated by means of Excel using the data from the first year (class width: $15 \mathrm{~min}$ ).

1.5.3 $P_{\mathrm{N}}$ versus photosynthetic photon flux density (PPFD)

Original data of the first year from both plots were averaged within $5 \mathrm{~min}$. Wide classes and their means that occurred in the temperature range $26-31{ }^{\circ} \mathrm{C}$ and at ALVPD $<40 \mathrm{~Pa} / \mathrm{kPa}$ were selected by SAS 9.2 program. Thereafter these results were converted to values of $P_{\mathrm{N}}$ on dry mass basis by using SLA and plotted against PPFD. One linear regression was fitted to the initial slope of the saturation curve by using Marquardt's least-square approximation.

1.5.4 $P_{\mathrm{N}}$ versus internal $\mathrm{CO}_{2}$ concentration $\left(\mathrm{C}_{\mathrm{i}}\right)$

Those five-minute means of $P_{\mathrm{N}}$ that occurred at PPFD $>800 \mu \mathrm{mol}$ photons $/\left(\mathrm{m}^{2} \cdot \mathrm{s}\right)$ and leaf surface temperature ( $\left.\mathrm{T}_{\text {leaf }}\right) 26-31^{\circ} \mathrm{C}$ were selected by SAS 9.2 program from the data collected near the former river bank in 2008. The selected data were averaged for 20 $\mu \mathrm{mol} \mathrm{CO} / \mathrm{mol}$ wide classes (exception class I: 70-130 $\mu \mathrm{mol} \mathrm{CO}_{2} / \mathrm{mol}$ ) and then plotted against $\mathrm{C}_{\mathrm{i}}$ in the given range of $50-310 \mu \mathrm{mol} \mathrm{CO} / \mathrm{mol}$.

1.5.5 $P_{\mathrm{N}}$ versus $\mathrm{T}_{\text {leaf }}$

Those five-minute means that occurred at PPFD $>800$ $\mu \mathrm{mol}$ photons $/\left(\mathrm{m}^{2} \cdot \mathrm{s}\right)$ and $\mathrm{g}_{\mathrm{s}}>90 \mathrm{mmol} \mathrm{H}_{2} \mathrm{O} /\left(\mathrm{m}^{2} \cdot \mathrm{s}\right)$ from the first year were selected by means of SAS 9.2 program, and then the mean response of $P_{\mathrm{N}}$ to increasing $\mathrm{T}_{\text {leaf }}$ was plotted.

\subsubsection{E and $g_{s}$ versus ALVPD}

Those five-minute means of $\mathrm{E}$ and $\mathrm{g}_{\mathrm{s}}$ that occurred at PPFD $>800 \mu \mathrm{mol}$ photons $/\left(\mathrm{m}^{2} \cdot \mathrm{s}\right)$ from the first year were chosen by the SAS 9.2 program. The selected data were averaged for $5 \mathrm{~Pa} / \mathrm{kPa}$ wide classes (exception: ALVPD-class $>80 \mathrm{~Pa} / \mathrm{kPa}$ ). Response curves were fitted to the means by using Marquardt's least-square approximation.

\subsection{7 $\quad$ E versus $T_{\text {leaf }}$}

All data collected in both years on both plots at PPFD $>800 \mu \mathrm{mol}$ photons $/\left(\mathrm{m}^{2} \cdot \mathrm{s}\right)$ were selected (by SAS 9.2 program). Means of $\mathrm{E}$ for $2^{\circ} \mathrm{C}$ wide temperature classes were calculated and plotted against $T_{\text {leaf }}$. Response curve was fitted to these means by using Marquardt's least-square approximation.

Differences between the stands, presented in Table 1, were tested by means of $t$-tests and one-factorial variance analyses (ANOVA).

\section{Results}

\subsection{SLA and $\mathrm{C} / \mathrm{N}$ ratio}

Leaves were larger near the desert edge ( $\delta$ between the means, $38 \%$ ), but also slightly but significantly lower in SLA ( $\delta$ between the means of SLA, 3.2\%; Table 1).

$\mathrm{N}$ contents (2007), with values of $1.3 \%-1.4 \%$, were comparably low, i.e. they were around two thirds of the contents in P. nigra (2.0\%) from Central Europe. $\mathrm{N}$ contents of leaves from the bank of the former river were $7 \%$ lower $(P<0.1)$ and $\mathrm{C}$ contents were $1 \%$ higher than near the desert. Accordingly, the difference in $\mathrm{C} / \mathrm{N}$ was close to statistical significance. 
Table 1 Means of single surface leaf area, specific leaf area (SLA) and leaf $\mathrm{C} / \mathrm{N}$ ratio for Populus euphratica from two different stands (former river bank, desert edge) in Northwest China and for P. nigra in Central Europe

\begin{tabular}{|c|c|c|c|c|}
\hline & \multicolumn{2}{|c|}{ P. euphratica } & \multicolumn{2}{|r|}{ P. nigra } \\
\hline & $\begin{array}{l}\text { Former river bank } \\
(n=381)\end{array}$ & $\begin{array}{l}\text { Desert edge } \\
(n=300)\end{array}$ & $P$ & $\begin{array}{l}\text { Sun leaves } \\
(n=5)\end{array}$ \\
\hline $\begin{array}{l}\text { Surface leaf } \\
\text { area }\left(\mathrm{cm}^{2}\right)\end{array}$ & $9.8 \pm 4.2$ & $13.6 \pm 3.7$ & $<0.001$ & $12.4 \pm 3.4$ \\
\hline $\operatorname{SLA}\left(\mathrm{cm}^{2} / \mathrm{g}\right)$ & $69.2 \pm 11.3$ & $67.0 \pm 10.0$ & 0.003 & $115.1 \pm 19.0$ \\
\hline $\mathrm{C} / \mathrm{N}$ ratio & $33.5 \pm 5.5$ & $35.9 \pm 4.5$ & 0.051 & $22.5 \pm 1.5$ \\
\hline
\end{tabular}
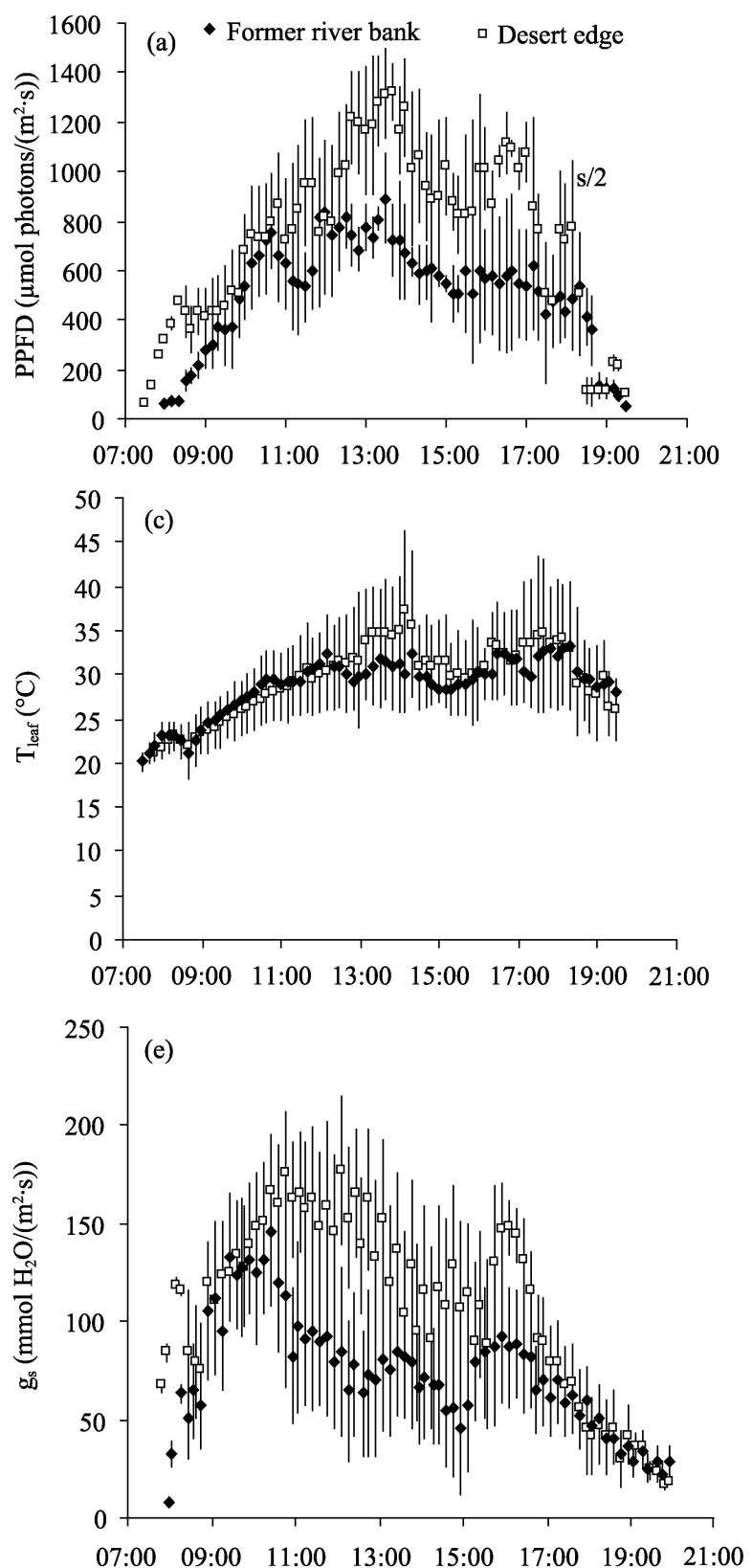

2.2 Daily courses of PPFD, $P_{\mathrm{N}}, \mathrm{T}_{\text {leaf }}, \mathrm{E}, \mathrm{g}_{\mathrm{s}}$, and ALVPD

There was a great variability of $P_{\mathrm{N}}$ and E between the leaves of $P$. euphratica. Nevertheless, mean daily courses showed that highest $P_{\mathrm{N}}$ and $\mathrm{E}$ rates were mainly reached during the first half of the day before noon in both stands (Figs. $2 b$ and d). Rapid decrease occurred afterwards and was followed by a recovery
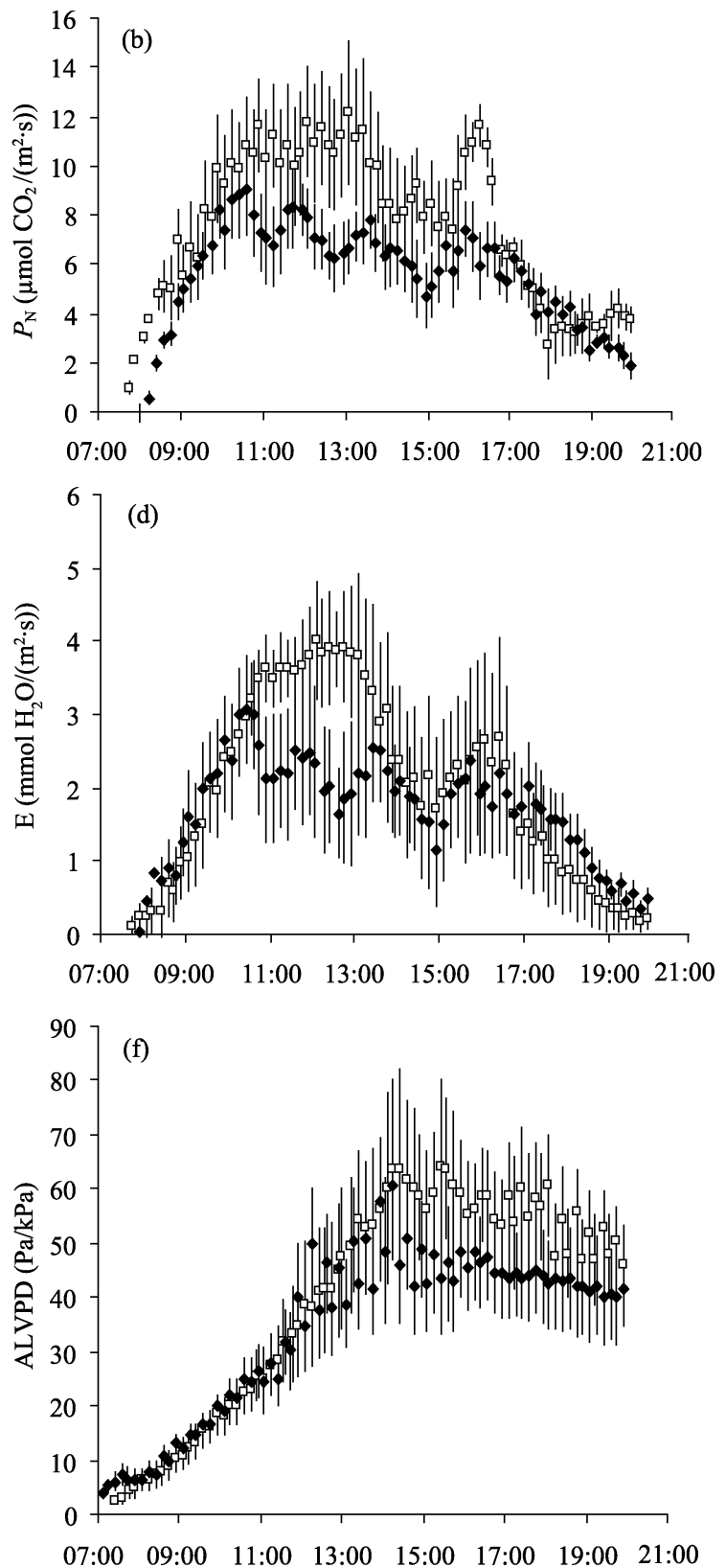

Fig. 2 Mean daily courses of photosynthetic photon flux density (PPFD, (a)), $\mathrm{CO}_{2}$ net assimilation $\left(P_{\mathrm{N}}\right.$, (b)), leaf surface temperature $\left(\mathrm{T}_{\text {leaf }},(\mathrm{c})\right)$, transpiration $(\mathrm{E},(\mathrm{d}))$, stomatal conductance $\left(\mathrm{g}_{\mathrm{s}}, \mathrm{H}_{2} \mathrm{O} ;(\mathrm{e})\right)$, and air to leaf water vapor pressure deficit (ALVPD, (f)) of Populus euphratica leaves at two different stands in Northwest China during 19 July-16 August 2007 at $\mathrm{g}_{\mathrm{s}}>1 \mathrm{mmol} \mathrm{H} \mathrm{O} /\left(\mathrm{m}^{2} \cdot \mathrm{s}\right)(n=9$ daily courses for desert edge; $n=13$ daily courses for former river bank; bars: standard deviation with exception of PPFD s/2) 
with a second slightly lower maximum around 16:00 p.m.

Mean $g_{s}$ of leaves near the bank of the former river and of those close to the edge of the desert took parallel daily courses (Fig. 2e). They increased steeply from sunrise up to peaks between 10:30 and 12:00 a.m. A lower second maximum could be observed around 16:00 p.m. and afterwards $\mathrm{gs}_{\mathrm{s}}$ decreased continuously towards dusk. However, $g_{s}$ of leaves on trees near the desert dunes reached higher values during the whole day. The difference between the $g_{s}$ maxima amounted to $56 \mathrm{mmol} \mathrm{H} \mathrm{O} /\left(\mathrm{m}^{2} \cdot \mathrm{s}\right)$.

$\mathrm{E}$ and $\mathrm{g}_{\mathrm{s}}$ courses differed timely: $\mathrm{g}_{\mathrm{s}}$ reached maxima $1.5 \mathrm{~h}$ earlier than $\mathrm{E}$ and decreased earlier, too (Figs. $2 \mathrm{~d}$ and $\mathrm{e}$ ). Both $\mathrm{g}_{\mathrm{s}}$ and $\mathrm{E}$ took daily courses different from the courses of ALVPD. Near the bank of the former river, the absolute maximum of ALVPD amounted to $92 \mathrm{~Pa} / \mathrm{kPa}$ and near the desert it reached $109 \mathrm{~Pa} / \mathrm{kPa}$ during the first measuring period.

\subsection{WUE}

Mean WUE daily courses differed between the two stands (Fig. 3). Near the bank of the former river, efficiency (on average) tended to increase slightly or remained stable from morning to noon and there was a certain trend to decrease until the evening, whilst the means of the desert edge leaves reached high values

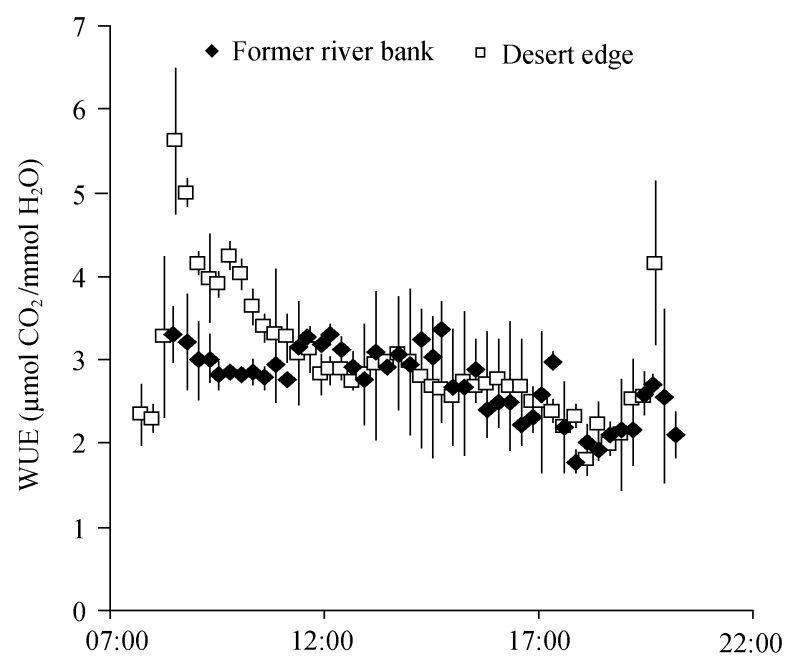

Fig. 3 Mean daily courses of water use efficiency (WUE) as quotient of $\mathrm{CO}_{2}$ net assimilation $\left(P_{\mathrm{N}}\right)$ and transpiration $(\mathrm{E})$ for Populus euphratica leaves from two different stands in Northwest China during 19 July-16 August 2007 ( $n=9$ daily courses for desert edge; $n=13$ daily courses for former river bank) in the morning followed by a rapid decrease towards the afternoon with a subsequent increase during the evening.

\section{$2.4 P_{\mathrm{N}}$ and PPFD}

A few leaves on trees near the former river bank reacted more sensitively upon low PPFD and reached saturation at a lower level than those on trees near the edge of the desert. However, on the average, leaves reached the PPFD compensation point at around 47 $\mu \mathrm{mol}$ photons $/\left(\mathrm{m}^{2} \cdot \mathrm{s}\right)$ on both plots. Close to the former river bank, saturation level approached 600-800 $\mu \mathrm{mol}$ photons $/\left(\mathrm{m}^{2} \cdot \mathrm{s}\right)$, whilst near the desert dunes saturation occurred at $700-900 \mu \mathrm{mol}$ photons $/\left(\mathrm{m}^{2} \cdot \mathrm{s}\right)$ without statistically significant difference between the maxima. In the linear part of the light, response curve quantum yield $(\alpha)$ amounted to $0.04 \mu \mathrm{mol} \mathrm{CO}_{2} /(\mathrm{g} \cdot \mathrm{s})$ $10^{-2}$ per $1 \mu \mathrm{mol}$ photons $/\left(\mathrm{m}^{2} \cdot \mathrm{s}\right)$ (Fig. 4).

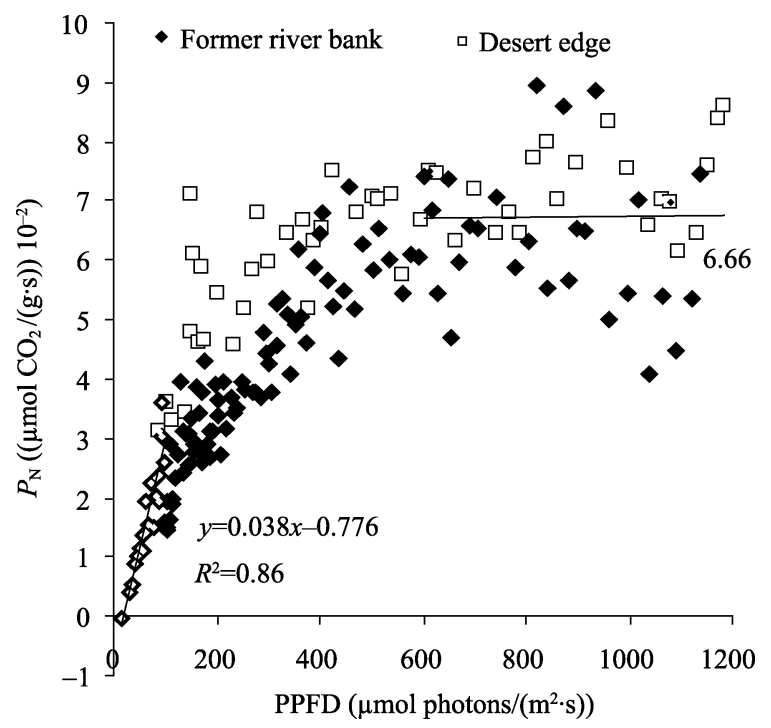

Fig. 4 Mean $\mathrm{CO}_{2}$ net assimilation $\left(P_{\mathrm{N}}\right)$ of Populus euphratica leaves in response to photosynthetic photon flux density (PPFD) from two stands in Northwest China at air to leaf water vapor pressure deficit (ALVPD) $<40 \mathrm{~Pa} / \mathrm{kPa}$ within the leaf surface temperature $\left(\mathrm{T}_{\text {leaf }}\right)$ interval $26-31^{\circ} \mathrm{C}$

\section{$2.5 \quad P_{\mathrm{N}} / \mathrm{C}_{\mathrm{i}}$ relationship}

Despite of a great variety between both plots and both years, it could be shown that $P_{\mathrm{N}}$ at PPFD values $>800$ $\mu \mathrm{mol}$ photons $/\left(\mathrm{m}^{2} \cdot \mathrm{s}\right)$ within the $\mathrm{T}_{\text {leaf }}$ range $26-31^{\circ} \mathrm{C}$ and at $\mathrm{g}_{\mathrm{s}}>90 \mathrm{mmol} \mathrm{H}_{2} \mathrm{O} /\left(\mathrm{m}^{2} \cdot \mathrm{s}\right)$ was linearly correlated with internal $\mathrm{C}_{\mathrm{i}}$ from 50 to $300 \mu \mathrm{mol} \mathrm{CO}_{2} / \mathrm{mol}$. In $2008, P_{\mathrm{N}}$ became positive at $54.8 \pm 11.5(\Gamma) \mu \mathrm{mol}$ 
$\mathrm{CO}_{2} / \mathrm{mol} \mathrm{C}_{\mathrm{i}}$ near the former river bank. From then on, the increase of $P_{\mathrm{N}}$ amounted to $5.3 \mu \mathrm{mol} \mathrm{CO} 2 /\left(\mathrm{m}^{2} \cdot \mathrm{s}\right)$ per $100 \mu \mathrm{mol} \mathrm{CO} / 2$ mol elevation of $\mathrm{C}_{\mathrm{i}}$ (Fig. 5).

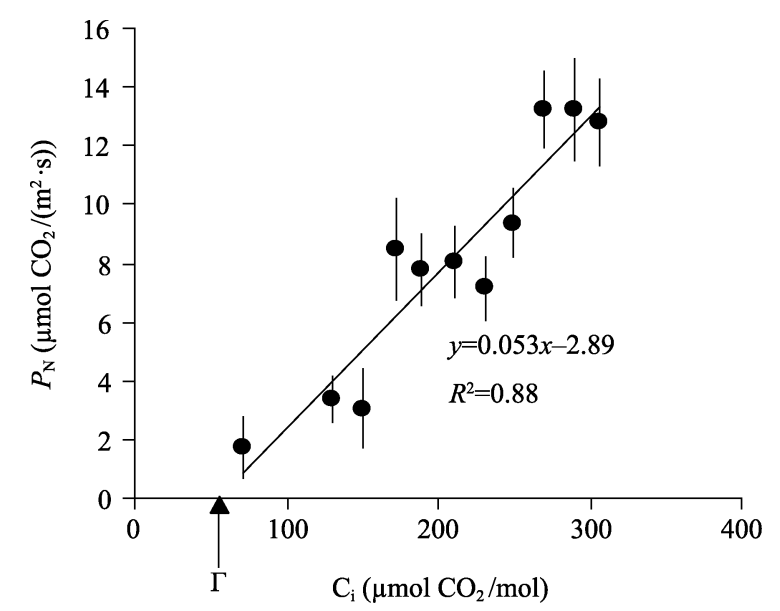

Fig. $5 \quad \mathrm{CO}_{2}$ net assimilation $\left(P_{\mathrm{N}}\right)$ of Populus euphratica leaves in response to leaf internal $\mathrm{CO}_{2}$ concentration $\left(\mathrm{C}_{\mathrm{i}}\right)$ at light saturation (photosynthetic photon flux density (PPFD) $>800 \mu \mathrm{mol}$ photons $\left./\left(\mathrm{m}^{2} \cdot \mathrm{s}\right)\right)$ near the former river bank in 2008. Arrow indicates $\mathrm{CO}_{2}$ compensation point $\Gamma$.

\section{6 $\mathrm{T}_{\text {leaf }}$ and $\mathrm{CO}_{2}$ gas exchange}

The data set from the first year was used to study the effect of $\mathrm{T}_{\text {leaf }}$ on $P_{\mathrm{N}}$. On the plot near the former river bank, $P_{\mathrm{N}}$ increased linearly with a rate of $1.1 \mu \mathrm{mol}$ $\mathrm{CO}_{2} /\left(\mathrm{m}^{2} \cdot \mathrm{s}\right)$ per $1^{\circ} \mathrm{C} \mathrm{T}_{\text {leaf }}$ elevation within the range 26-31 ${ }^{\circ} \mathrm{C}$. Near the desert edge, pre-suppositions for data evaluation $\left(\mathrm{PPFD}>800 \mu \mathrm{mol}\right.$ photons $/\left(\mathrm{m}^{2} \cdot \mathrm{s}\right)$, $\mathrm{g}_{\mathrm{s}}$ $\left.>90 \mathrm{mmol} \mathrm{H}_{2} \mathrm{O} /\left(\mathrm{m}^{2} \cdot \mathrm{s}\right)\right)$ were given from $22-25.5^{\circ} \mathrm{C}$ only. There, the increase came to $1.2 \mu \mathrm{mol} \mathrm{CO} /\left(\mathrm{m}^{2} \cdot \mathrm{s}\right)$ per $1{ }^{\circ} \mathrm{C} \mathrm{T}_{\text {leaf }}$ elevation. Above $30^{\circ} \mathrm{C}$, rates of $P_{\mathrm{N}}$ decreased gradually and steadily towards $40^{\circ} \mathrm{C}$ following parallel decreasing of $g_{s}$ in both stands.

\section{7 $E$ and $g_{s}$ in response to ALVPD}

Mean values of $E$ differed between the two stands in response to ALVPD (Fig. 6a). The desert edge leaves reached highest values already at $30 \mathrm{~Pa} / \mathrm{kPa}$, whilst leaves from the former river bank attained the peak at $40 \mathrm{~Pa} / \mathrm{kPa}$ (ALVPD). At high ALVPD ( $>40 \mathrm{~Pa} / \mathrm{kPa})$ and light saturation (PPFD $>800 \mu \mathrm{mol}$ photons $/\left(\mathrm{m}^{2} \cdot \mathrm{s}\right)$ ), mean water vapor loss by $\mathrm{E}$ was greater on the former river bank than at the desert edge.

Continuous decrease from maxima of $g_{s}$ occurred at $20 \mathrm{~Pa} / \mathrm{kPa}$ (ALVPD). Both curves approached each other and reached approximately the same low level of $\mathrm{g}_{\mathrm{s}}$ of $18 \pm 5 \mathrm{mmol} \mathrm{H} \mathrm{O} /\left(\mathrm{m}^{2} \cdot \mathrm{s}\right)$ at $\mathrm{ALVPD}>60 \mathrm{~Pa} / \mathrm{kPa}$ (Fig. 6b).

\subsection{E and $T_{\text {leaf }}$}

All data of $\mathrm{E}$ of the leaves from the former river bank and the desert edge were averaged for evaluating the effect of rising $\mathrm{T}_{\text {leaf }}$ upon $\mathrm{H}_{2} \mathrm{O}$ losses via $\mathrm{E}$ (Fig. 7). There was an increase of $\mathrm{E}$ up to a maximum of around $30^{\circ} \mathrm{C}\left(\beta_{1} \approx 0.41 \mathrm{mmol} \mathrm{H}_{2} \mathrm{O} /\left(\mathrm{m}^{2} \cdot \mathrm{s}\right)\right.$ per $1{ }^{\circ} \mathrm{C} \mathrm{T}_{\text {leaf }}$ increase) followed by gradually decreasing rates $\left(ß_{2} \approx 0.35 \mathrm{mmol} \mathrm{H} \mathrm{H}_{2} \mathrm{O} /\left(\mathrm{m}^{2} \cdot \mathrm{s}\right)\right.$ per $1^{\circ} \mathrm{C} \mathrm{T}_{\text {leaf }}$ increase $)$.
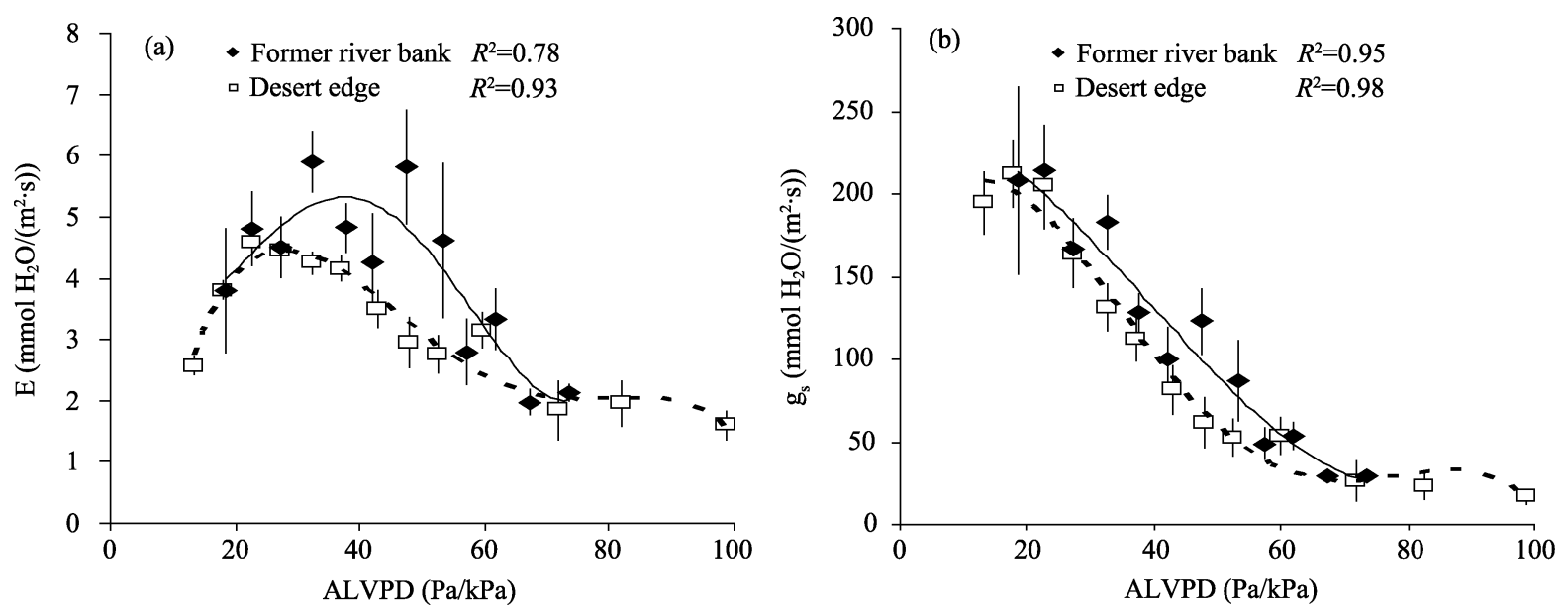

Fig. 6 Mean transpiration (E, (a)) and stomatal conductance $\left(\mathrm{g}_{\mathrm{s}}, \mathrm{H}_{2} \mathrm{O}\right.$; (b)) of Populus euphratica leaves at two different stands in Northwest China at photosynthetic photon flux density (PPFD) $>800 \mu \mathrm{mol}$ photons $/\left(\mathrm{m}^{2} \cdot \mathrm{s}\right)$ in response to air to leaf water vapor pressure deficit (ALVPD) ( $n=9$ daily courses for desert edge; $n=13$ daily courses for former river bank) 


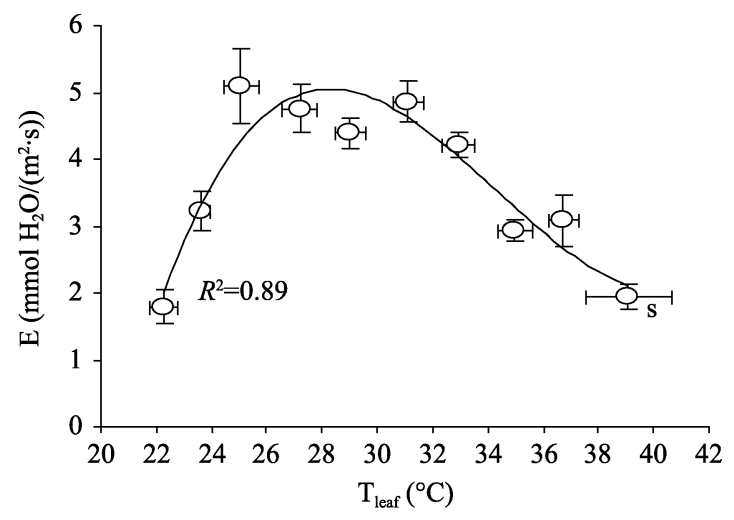

Fig. 7 Mean transpiration (E) of Populus euphratica leaves averaged for two stands in Northwest China in response to leaf surface temperature $\left(\mathrm{T}_{\text {leaf }}\right)\left(22-42^{\circ} \mathrm{C}\right)$ at photosynthetic photon flux density (PPFD) $>800 \mu \mathrm{mol}$ photons $/\left(\mathrm{m}^{2} \cdot \mathrm{s}\right)$ during 19 July-16 August 2007 and 28 June-9 July 2008 (data extracted from 34 daily courses)

\section{Discussion}

Leaves from trees near the sand dunes had greater areas on average than those from trees near the bank of the former river. This better area growth could have been caused by the lower conductivity of the upper soil (less salt) in comparison to the stand near the former river bank (Yu, 2008). Water supply of roots could not have had any measurable influence because groundwater levels were only slightly lower than near the former river bank ( $\mathrm{Yu}, 2008)$ and by far above the levels necessary for P. euphratica (Gries et al., 2003). $\mathrm{N}$ contents of around $1.4 \%$ in leaves from both stands, also found by Cao et al. (2011) during summer months in the Ejina oasis in the lower reaches of the Heihe River of northwestern China, can possibly be considered as typical for P. euphratica. According to Gries et al. (2005), the seasonal course of tree growth was nearly completed at the time of our sampling.

Although the statistically significant difference (SLA and $\mathrm{C} / \mathrm{N}$ ratio) between our two $P$. euphratica stands was small, the lower SLA as well as the little wider $\mathrm{C} / \mathrm{N}$ ratio of leaves at the desert edge (Table 1) indicates a tendency to concentrate more material per leaf area unit there.

E seldom reached the high levels that were obtained by $P$. euphratica in a salt tolerance experiment by Chen et al. (2003) and in total, $g_{s}$ values were also $30 \%-40 \%$ lower than those found by Zhou et al.
(2010) along the lower reaches of the Tarim River. On the other hand, the maxima of $\mathrm{E}$ as well as of $\mathrm{g}_{\mathrm{s}}$, which were reached in daily course during our measuring sessions, corresponded almost exactly with those found by Gries et al. (2003) during July-August in the Taklimakan Desert. However, in contrast to their results, our daily courses had two peaks: a very distinct one at midday, keeping the high level for about two hours, and a second short but also obvious one around 16:00 p.m. (Fig. 2). Thus, the curve forms resembled those simulated in a combined model of $\mathrm{CO}_{2}$ and $\mathrm{H}_{2} \mathrm{O}$ gas exchange at the leaf scale of $P$. euphratica for the months of July and August in Inner Mongolia, China (Zhu et al., 2011). The rapid increase from dawn to the midday maxima indicated that despite of high water losses to the surrounding air, all stomata had responded by opening and that water transport through the plant upwards was not restricted until a high threshold. Also restriction by vessel capacity cannot be assumed. The only gradually occurring decrease later on may have been either associated with patchy closure of stomata (Mott and Parkhurst, 1991) or coordinated gradually narrowing of opened pores. This regulation of the water loss via $\mathrm{E}$ is comparable with trees from the Mediterranean type ecosystem (Otieno et al., 2007) or even more efficient. There was a time delay of more than one hour of maximal rates of $E$ in comparison to those of $g_{s}$ in both stands (Fig. 2), indicating that there must have had been response to external or internal humidity based on effectively sensing water losses before E started to be reduced clearly. Our results, therefore, support the hypothesis of Farquhar (1978) that a pattern in which $\mathrm{E}$ first increases then begins to decline after a critical value of ALVPD is pointing to a 'feed-forward' response of stomata to humidity. Because reduction of both processes have already occurred 1-2 hours before ALVPD had reached the maxima, this hypothesis is supported additionally. The clear difference of $\mathrm{E}$ and $\mathrm{g}_{\mathrm{s}}$ between the two stands (Fig. 2) might have been due to the difference in SLA, i.e. the smaller and lighter leaves near the former river bank might have reacted more sensitively upon water losses to the ambient air than the more xeromorphic leaves near the desert edge. Salinity in the upper soil 
was also higher near the former river bank than near the desert edge (Yu, 2008), and that might have augmented the water stress in addition, and these factors together might have led to more reduced water losses caused by a more complete reduction of $\mathrm{E}$ in the stand near the former river bank. However, there was also a slightly lower level of ALVPD during the measurements at the former river bank that certainly will have caused lower E in total. Despite stable high levels of ALVPD in both cases until late in the evening, decrease of $E$ as well as that of $g_{s}$ was not continuous. Therefore, in both stands there must have been some filling of the water reservoirs in leaves so that stomata were apparently able to open or widen their pores, as indicated by the short recovery of $\mathrm{E}$ and $\mathrm{g}_{\mathrm{s}}$ around 16:00 p.m. Later on in the evening, decreasing light and decreasing ALVPD coincided and their influences on $\mathrm{E}$ and $\mathrm{g}_{\mathrm{s}}$ can not be considered independently from each other, like in the early morning.

WUE (the ratio of $P_{\mathrm{N}} / \mathrm{E}$ ), as one of the very important physiological characteristics in the process of plant growth, is considered as an objective index to evaluate water use and drought tolerance (Monclus et al., 2008; Cao et al., 2011). Bogeat-Triboulot et al. (2007) could experimentally show that $P$. euphratica operated at rather constant WUE under conditions of optimal water availability in the substrate. Because of relatively high groundwater levels at both of our stands, sufficient water supply can be assumed. The greater variability of the daily courses calculated for the stand desert edge show that WUE was influenced differently in comparison to WUE near the former river bank (Fig. 3). Most of the leaves near the former river bank maintained a stable low WUE throughout the day. In contrast, obviously leaves from the desert edge compensated their low $P_{\mathrm{N}} / \mathrm{E}$ ratio throughout most of the day, because they widened the ratio in favor of $P_{\mathrm{N}}$ early in the morning and late in the evening, in contrast to leaves from the former river bank which revealed slightly opposite trends during those times of the day (Fig. 4).

Ma et al. (1997) found that $P$. euphratica has a high $\mathrm{CO}_{2}$ compensation point $(\Gamma, 150 \mu \mathrm{mol} \mathrm{CO} / \mathrm{mol})$ and a PPFD saturation level of $2,800 \mu \mathrm{mol}$ photons $/\left(\mathrm{m}^{2} \cdot \mathrm{s}\right)$ under controlled conditions. During our field studies,
PPFD $>1,200 \mu \mathrm{mol}$ photons $/\left(\mathrm{m}^{2} \cdot \mathrm{s}\right)$ was only sometimes reached near the desert edge, and leaves seemed to be lightly saturated at least around $1.200 \mu \mathrm{mol}$ photons $/\left(\mathrm{m}^{2} \cdot \mathrm{s}\right)$; leaves from the former river bank showed no increase of $P_{\mathrm{N}}$ at PPFD $>800 \mu \mathrm{mol}$ photons $/\left(\mathrm{m}^{2} \cdot \mathrm{s}\right)$. However, the highest level of $P_{\mathrm{N}}$ that was reached in our study $\left(13 \mu \mathrm{mol} \mathrm{CO}_{2} /\left(\mathrm{m}^{2} \cdot \mathrm{s}\right)\right)$ corresponds nearly with the maximum of $15 \mu \mathrm{mol}$ $\mathrm{CO}_{2} /\left(\mathrm{m}^{2} \cdot \mathrm{s}\right)$ found by Zhou et al. (2010) at $40^{\circ} \mathrm{C}$ and was lower than the one found by Chen et al. (2006b; 15-25 $\left.\mu \mathrm{mol} \mathrm{CO}_{2} /\left(\mathrm{m}^{2} \cdot \mathrm{s}\right)\right)$. Enough data for adjusting the $\mathrm{CO}_{2}$ compensation along the $\mathrm{C}_{\mathrm{i}}$ gradient were only available from our measurements during the second year on the former river bank plot. In contrast to Ma et al. (1997; $\left.\Gamma, 150 \mu \mathrm{mol} \mathrm{CO}_{2} / \mathrm{mol}\right)$, we found a lower mean of $\mathrm{CO}_{2}$ compensation point $(\Gamma, 55 \mu \mathrm{mol}$ $\mathrm{CO}_{2} /$ mol; Fig. 5).

Only those mean values from the daily courses of $\mathrm{E}$ and $\mathrm{g}_{\mathrm{s}}$ of $P$. euphratica in response to ALVPD were used for Fig. 6. They were measured at PPFD $>800$ $\mu \mathrm{mol}$ photons $/\left(\mathrm{m}^{2} \cdot \mathrm{s}\right)$ in order to exclude as far as possible effects of low light on stomata performance in the morning and in the evening. The results corroborate the outcome of the investigation by Thomas et al. (2008) who found a similarly close relation between $\mathrm{g}_{\mathrm{s}}$ and ALVPD and concluded that $70 \%$ of the variation in stomatal resistance of this species can be explained by changes of ALVPD. In total, all our curves show that performance of $P$. euphratica belongs to a regime under which $\mathrm{E}$ and $\mathrm{g}_{\mathrm{s}}$ remain constant or begin to decrease as ALVPD is increasing. However, P. euphratica seems to follow a modification of that 'regime' because first, $\mathrm{E}$ and $\mathrm{g}_{\mathrm{s}}$ increased up to distinct maxima before decrease occurred. The subsequent steep decrease of $g_{s}$ indicated continuous closure of stomata. E followed but remained on the high level of up to $40 \mathrm{~Pa} / \mathrm{kPa}$ ALVPD before it decreased. This shows that $P$. euphratica is able to maintain unrestricted gas exchange within the range $20-40 \mathrm{~Pa} / \mathrm{kPa}$ ALVPD (at high groundwater levels). Therefore, $P$. euphratica can be considered as an exception within the genus, because poplars are normally known to be very sensitive to water stress in general (Larchevêque et al., 2011). Our curves (Fig. 6) show that full closure 
of stomata had been achieved between 50 and 60 $\mathrm{Pa} / \mathrm{kPa}$ ALVPD without clear differences between the two stands. The relatively great losses of water vapor at high evaporative demands (ALVPD $>60 \mathrm{~Pa} / \mathrm{kPa}$ ), which reaches $30 \%$ of the maximum of $\mathrm{E}$, indicates high E via the entire leaf surface during stomatal closure. However, losses through the entire surface cannot exactly be estimated because at least some stomata opened in the afternoon despite of ALVPD >60 $\mathrm{Pa} / \mathrm{kPa}$ as could be shown before by means of the daily courses (Fig. 2). Thus, at stomatal closure, leaves of $P$. euphratica must also be dependent on water replenishment from the ground especially during summer months. The revealed differences between the two stands might have had been due to the differences in environmental conditions as was already discussed. Fu et al. (2011) emphasize that air temperature belongs to the dominant factors influencing gas exchange characteristics and water potential of broad-ovate leaves of $P$. euphratica. Of course, the factors $\mathrm{T}_{\text {leaf }}$ and $\mathrm{E}$ are closely correlated. Very likely a covariance effect of additional variables (e.g. water deficits) could be expected, too. Nevertheless, the turning point of $\mathrm{E}$ rates that we found at $29-30^{\circ} \mathrm{C}$ for leaves on trees near the former river bank was scarcely to be expected. Up to this temperature, $\mathrm{E}$ increased and when $>30^{\circ} \mathrm{C}$, E started to decrease gradually and continuously, indicating successive stomatal closure in dependence of $\mathrm{T}_{\text {leaf }}$. Near the desert edge, $\mathrm{T}_{\text {leaf }}$ from $26-30^{\circ} \mathrm{C}$ were too low for a reliable interpretation. However, the decrease of $\mathrm{E}$ above $30^{\circ} \mathrm{C}$ also took a course parallel to that measured at the other stand. Therefore, data were averaged for both stands (Fig. 7).

\section{Conclusions}

Although differences in leaf attributes were measured, only slight differences in gas exchange parameters could be found. Therefore, we conclude that impacts of micro-climatic site conditions on gas exchange rates were not the driving factors for apparent changes of stand structure along the environmental gradient. In general, $P$. euphratica is capable to maintain gas exchange at comparatively high air to leaf water vapor pressure deficits and high temperatures, and if thresh- olds, quantified in this paper, are passed over, its leaves start to reduce water vapor losses effectively. A future possibility would be to use our data, together with results of former investigations, to calculate the water release of all trees and stands to the atmosphere using leaf area indices determined by means of satellite images that are calibrated via terrestrial surveys.

\section{Acknowledgements}

This research was funded by the German Academic Exchange Service, PPP-China (D/06/00362). Our thanks go to Dr. YanHong LI and Erik BUTZ for a great deal of the field measurements. We also thank Xiang GAO and LiHua GAO at the administration of the Ebinur Lake National Nature Reserve in Xinjiang, Northwest China, for their friendly help during our visits.

\section{References}

Aphalo P J, Jarvis P G. 1991. Do stomata respond to relative humidity? Plant, Cell \& Environment, 14(1): 127-132.

Arndt S K, Arampatsis C, Foetzki A, et al. 2004. Contrasting patterns of leaf solute accumulation and salt adaptation in four phreatophytic desert plants in a hyperarid desert with saline groundwater. Journal of Arid Environments, 59(2): 259-270.

Bogeat-Triboulot M B, Brosché M, Renaut J, et al. 2007. Gradual soil water depletion results in reversible changes of gene expression, protein profiles, ecophysiology, and growth performance in Populus euphratica, a poplar growing in arid regions. Plant Physiology, 143(2): 876-892.

Bruelheide H, Vonlanthen B, Jandt U, et al. 2010. Life on the edge-to which degree does phreatic water sustain vegetation in the periphery of the Taklamakan Desert? Applied Vegetation Science, 13(1): 56-71.

Cao S K, Feng Q, Su Y H, et al. 2011. Research on the water use efficiency and foliar nutrient status of Populus euphratica and Tamarix ramosissima in the extreme arid region of China. Environmental Earth Sciences, 62(8): 1597-1607.

Chang Y, Chen S L, Yin W L, et al. 2006. Growth, gas exchange, abscisic acid and calmodulin response to salt stress in three poplars. Journal of Integrative Plant Biology, 48(3): 286-293.

Chen S L, Li J K, Wang S S, et al. 2001. Salt, nutrient uptake and transport, and ABA of Populus euphratica; a hybrid in response to increasing soil NaCl. Trees, 15(3): 186-194.

Chen S L, Li J K, Fritz E, et al. 2002. Sodium and chloride distribution in roots and transport in three poplar genotypes under increasing $\mathrm{NaCl}$ stress. Forest Ecology and Management, 168(1-3): 217-230.

Chen S L, Li J K, Wang T H, et al. 2003. Gas exchange, xylem ions and abscisic acid response to $\mathrm{Na}^{+}$-salts and $\mathrm{Cl}^{-}$-salts in Populus euphratica. Acta Botanica Sinica, 45(5): 561-566.

Chen Y N, Zilliacus H, Li W H. 2006a. Ground-water level effects plant species diversity along the lower reaches of the Tarim River. Journal 
of Arid Environments, 66(2): 231-246.

Chen Y P, Chen Y N, Li W H, et al. 2006b. Characterization of photosynthesis of Populus euphratica grown in the arid region. Photosynthetica, 44(4): 622-626.

Farquhar G D. 1978. Feedforward responses of stomata to humidity. Australian Journal of Plant Physiology, 5(6): 787-800.

Fu A H, Li W H, Chen Y N, et al. 2011. Analysis of dominant factors influencing moisture change of broad-ovate leaves of Populus euphratica Oliv. in extremely arid region. Photosynthetica, 49(2): 295-308.

Fung L E, Wang S S, Altman A, et al. 1998. Effect of $\mathrm{NaCl}$ on growth, photosynthesis ion and water relations of four poplar genotypes. Forest Ecology and Management, 107(1-3): 135-146.

Gries D, Zeng F, Foetzki A, et al. 2003. Growth and water relations of Tamarix ramosissima and Populus euphratica on Taklamakan Desert dunes in relation to depth to a permanent water table. Plant, Cell \& Environment, 26(5): 725-736.

Gries D, Foetzki A, Arndt S K, et al. 2005. Production of perennial vegetation in an oasis desert transition zone in NW China-allometric estimation, and assessment of flooding and use effects. Plant Ecology, 181(1): 23-43.

Hukin D, Cochard H, Dreyer E, et al. 2005. Cavitation vulnerability in roots and shoots: does Populus euphratica Oliv., a poplar from arid areas of Central Asia, differ from other poplar species? Journal of Experimental Botany, 56(418): 2003-2010.

Khamzina A, Lamers J P A, Vlek P L G. 2008. Tree establishment under deficit irrigation on degraded agricultural land in the lower Amu Darya River region, Aral Sea Basin. Forest Ecology and Management, 255(1): 168-178.

Lamers J P A, Khamzina A, Worbes M. 2006. The analyses of physiological and morphological attributes of 10 tree species for early determination of their suitability to afforest degraded landscapes in the Aral Sea Basin of Uzbekistan. Forest Ecology and Management, 221(1-3): 249-259.

Larchevêque M, Maurel M, Desrochers A, et al. 2011. How does drought tolerance compare between two improved hybrids of balsam poplar and an unimproved native species? Tree Physiology, 31(3): 240-249.

Ma H C, Fung L, Wang S S, et al. 1997. Photosynthetic response of Populus euphratica to salt stress. Forest Ecology and Management, 93(1-2): 55-61.

Meinzer F C, Grantz D A. 1991. Coordination of stomatal, hydraulic and canopy boundary layer properties: do stomata balance conductances by measuring transpiration? Physiologia Plantarum, 83(2): 324-329.
Monclus R, Dreyer E, Villar M, et al. 2006. Impact of drought on productivity and water use efficiency in 29 genotypes of Populus deltoidis $\times$ Populus nigra. New Phytologist, 169(4): 765-777.

Monteith J L. 1995. A reinterpretation of stomatal responses to humidity. Plant, Cell \& Environment, 18(4): 357-364.

Mott K A, Parkhurst D F. 1991. Stomatal response to humidity in air and helox. Plant, Cell \& Environment, 14(5): 509-515.

Otieno D O, Schmidt M W T, Kurz-Besson C, et al. 2007. Regulation of transpirational water loss in Quercus suber trees in a Mediterranean-type ecosystem. Tree Physiology, 27(8): 1179-1187.

Säumel I, Ziche D, Yu R, et al. 2011. Grazing as a driver for Populus euphratica woodland degradation in the semi-arid Aibi Hu region, northwestern China. Journal of Arid Environments, 75(3): 265-269.

Thomas F M, Arndt S K, Bruelheide H, et al. 2000. Ecological basis for sustainable management of the indigenous vegetation in a Central-Asian desert: presentation and first results. Journal of Applied Botany, 74(5-6): 212-219.

Thomas F M, Foetzki A, Arndt S K, et al. 2006. Water use by perennial plants in the transition zone between river oasis and desert in NW China. Basic and Applied Ecology, 7(3): 253-267.

Thomas F M, Foetzki A, Gries D, et al. 2008. Regulation of the water status in three co-occuring phreatophytes at the southern fringe of the Taklamakan desert. Journal of Plant Ecology, 1(4): 227-235.

Walter H, Box E O, Hilbig W. 1983. The deserts of Central Asia. In: West N E. The Deserts of Central Asia: Temperate Deserts and Semi-Deserts. Amsterdam: Elsevier, 193-236.

Yu R D. 2008. Forest development along the former river Aqikesu in the Aibi Hu National Nature Reserve in P.R. China. Ph.D. Dissertation. TU-Berlin: Technical University of Berlin.

Zhao Y, Zhao C Y, Xu Z L, et al. 2012. Physiological responses of Populus euphratica Oliv. to groundwater table variations in the lower reaches of Heihe River, Northwest China. Journal of Arid Land, 4(3): 281-291.

Zhou H H, Chen Y N, Li W H, et al. 2010. Photosynthesis of Populus euphratica in relation to groundwater depths and high temperature in arid environment, northwest China. Photosynthetica, 48(2): 257-268.

Zhu G F, Li X, Su Y H, et al. 2010. Parametrization of coupled $\mathrm{CO}_{2}$ and $\mathrm{H}_{2} \mathrm{O}$ gas exchange model at the leaf scale of Populus euphratica. Hydrology and Earth System Sciences, 14(3): 419-431.

Zhu G F, Li X, Su Y H, et al. 2011. Seasonal fluctuations and temperature dependence in photosynthetic parameters and stomatal conductance at leaf scale of Populus euphratica Oliv. Tree Physiology, 31(2): 178-195. 